DOI: $10.31558 / 2308-1902.2018 .26 .12$

УДК 821.161.2.09(092)Алейнік

Жанна ШАЛАДОНАВА

кандыдат філалагічных навук, Цэнтр даследаванняў беларускай культуры, мовы і літаратуры НАН Беларусі

\title{
ПРАСТОРАВЫЯ ВОБРАЗЫ Ў ПАЭТЫЧНЫМ ДЫСКУРСЕ БАРЫСА АЛЕЙНІКА
}

У статті розкриваються ідейно-естетичні особливості просторових образів у поезії Бориса Олійника, осмислюється їх символічна змістовність в авторській самоідентифікації, виявленні життєвого і творчого кредо, трансляції роздумів, почуттів, настроїв. Автор статті приходить до висновку, що використання просторових образів у поетичному дискурсі Б. Олійника ніколи не буває випадковим, обмеженим декоративними функціями. Виразна просторова конкретизація і об’ємність образів художнього малюнка дає можливість наочно і природно обгрунтувати відображені в нього моральні категорії, філософські рефлексії, емоційно-почуттєву сферу.

Ключові слова: просторові образи, символ, національний, самоідентифікація.

Самаўсведамленне, самаідэнтыфікацыя асобнага чалавека і цэлага народа ва ўсім спектры ўнікальных і знакавых характарыстык адбываецца, як правіла, ва ўвязцы з канкрэтнай прасторай, як месцам жыцця і дзейнасці. Навакольны свет з'яўляецца важнейшым модусам існавання, найбольш відавочным спосабам праяўлення феномена чалавека ў адзінстве яго ментальных, сацыяльных i фізічных характарыстык. У гуманітарным мысленні прастора навакольнага свету ўспрымаецца не толькі як аб’ект пазнання, але, найперш, як прадмет эмацыянальна і псіхалагічна насычанага перажывання. Знешні, фізічны свет і ўнутрана-духоўны існуюць супярэчлівым дыялектычным адзінстве, узаемаабумоўленасці і ўзаемадапаўняльнасці. Д. Ліхачоў называе прыроду «выяўленнем душы народа», а пейзаж краіны - «элементам нацыянальнай культуры», падкрэсліваючы тым самым сувымернасць экасістэмы і духоўнай культуры. У вырашэнні гэтых задач актыўна задзейнічаны ўвесь арсенал мастацкіх сродкаў, сярод якіх прасторава-ландшафтныя характарыстыкі спрыяюць захаванню найбольш аб’ектыўнага i дакладнага ракурсу адлюстравання быцця, валодаюць неабходнай сэнсава-інфармацыйнай змястоўнасцю ў самавызначэнні і самаідэнтыфікацыі асобы і нацыі, акрэсліваюцца контуры 
духоўна-ментальнага аблічча чалавека і грамадства як важных складнікаў структураванага, шматмернага ўніверсуму. Мэта даследавання палягае ў раскрыцці мастацкіх асаблівасцей прасторавых вобразаў у паэзіі Барыса Алейніка, асэнсаванні іх ідэйна-эстэтычнай змястоўнасці ў выяўленні творчай індывідуальнасці пісьменніка.

Тэарэтыка-аналітычнае асэнсаванне прасторавых катэгорый у мастацкіх тэкстах адлюстравана ў працах М. Бахціна, Д. Ліхачова, Ю. Лотмана, I. Нікіцінай, $\quad$ В. Топарава, Б. Успенскага $\quad$ i iнш. Асноўная праява i фундаментальная характарыстыка рэчаіснасці, адзін са структураўтваральных элементаў культуры і літаратуры, катэгорыя прасторы акрэслівае асноўныя арыенціры, у адпаведнасці з якімі будуецца любая карціна свету, у тым ліку індывідуальна-аўтарская ў мастацкім космасе пісьменніка. На гэта звяртае ўвагу Ю. Лотман: «Самыя агульныя сацыяльныя, рэлігійныя, палітычныя, маральна-духоўныя мадэлі свету, пры дапамозе якіх чалавек на розных этапах сваёй духоўнай гісторыі асэнсоўвае навакольнае жыццё, аказваюцца нязменна надзелены прасторавымі характарыстыкамі» [1, с. 256]. У прасторавых вобразах закладзены вялікі выяўленчы патэнцыял, магчымасці трансляцыі разнастайнай палітры чалавечых пачуццяў, роздумаў, настрояў.

Мастака самабытнай і яркай творчай індывідуальнасці, Барыса Алейніка вылучае памежная адкрытасць лірычнай споведзі, тонкая аналітыка духоўнага свету чалавека і разам з тым па-філасофску ўдумлівы погляд на рэчаіснасць, сатырычная i грамадзянская завостранасць паэтычнага дара, патрыятычная заангажаванасць. Здаецца, у мастацкай карціне свету аўтара 3 падобным філасофска-аналітычным складам мыслення прасторавыя вобразы набываюць дастаткова абагулены, нават умоўны характар. Сапраўды, класічныя разгорнутыя пейзажныя замалёўкі з уласцівымі ім атрыбутамі ўкраінскага прыроднага ландшафту i побыту не дамінуюць у паэзіі Б. Алейніка. Натуральна-прыродны фактар у ёй трансфармуецца ў крэатыўную стыхію, якая валодае магчымасцямі перадачы аксіялагічнай, духоўна-філасофскай мястоўнасці 
насычанасці быцця. Мастацкі погляд канвертуе звычайныя прасторавыя аб’екты ў філігранна выпісаныя запамінальныя вобразы-сімвалы.

Ці не галоўная ўласцівасць і важнейшая характарыстыка паэтычных замалёвак Б. Алейніка - напружаны рух, рух па асваенню навакольнай прасторы і сімвалічнай прасторы чалавечай душы. М. Ільніцкі лічыць: «паэзія Б.Алейніка асабліва прываблівае тым, што яна заўжды ў руху, заўжды ў станаўленні: дасягнутае ўчора робіцца адпраўным пунктам для сённяшніх пошукаў. А сённяшнія здабыткі праектуюцца ў новую якасць» [2, c. 108]. Памкнёны рух забяспечвае абвостранасць і свежасць успрыняцця свайго часу, сваей эпохі ў праекцыі на вечныя ўніверсаліі, а яго ўсеахопнасць дазваляе разгледзець і перадаць гераічную напоўненасць, змястоўную праўду i прыгажосць паўсядзённасці. Паэму «Рух» распачынае разгорнуты ў прасторы і часе малюнак спрадвечнага ўсеагульнага перамяшчэння:

Це долею так накреслено,

Що все життя на колесах ми.

Вагони годин хитаються,

Та станції все минаються

$$
\text { [3, c. 363]. }
$$

У грэчаскай мове слова «сhora» азначае прастора, іду наперад, распаўсюджваюся, рухаюся. Платонам «сhora» тлумачыцца як «тая адзіная абмежаваная прастора, прызначаная для дадзенага народа, Бога, роду людзей або рэчаў, дзе яны могуць нараджацца і развівацца згодна сваёй прыродзе, i варта ім толькі пераступіць мяжу, як яны перастануць быць сабой» $[4$, с. $62-$ 63]. Б. Алейнікам рух i развіццё атаясамліваюцца 3 нацыянальным прасторавым фактарам, абумоўліваюцца ім.

Скажу лиш: де б ти не ходив,

Та - хай засвідчує перо! -

Що не знайти дивніше 3 див,

Як Україна і Дніпро....[3, с. 38] 
Б. Алейнік акрэслівае ўкраінскую нацыянальную прастору апасродкам пазнавальных, ключавых, эмблематычных прасторавых топасаў. Так, аўтар прэзентуе фенаменальнасць Дняпра, унікальнага прыроднага аб’екта ўкраінскіх ландшафтаў у непарыўным сімвалічна-знакавым адзінстве 3 культурна-гістарычнай памяццю Украіны.

Ёсць у Б. Алейніка і верш, прысвечаны Беларусі, у якім ён як мудры летапісец звяртаецца да памяці вайны, праз сімвалічныя прасторавыя вобразы бяроз, дрэў-ваяроў, прыводзіць сумнавядомую статыстыку: «Три берези ростуть. А четверта вогнём» [3, с 39]. Аўтар выказвае самыя цёплыя пачуцці роднаснасці, шчырае спадзяванне на духоўнае яднанне са шматпакутнай беларускай зямлёй. Прычым, ідэя духоўнага яднання наглядна і жывапісна ўвасоблена аўтарам праз прасторавыя суадносіны-збліжэнне бяроз і явара:

О дозволь, Білорусь,

перейшовши печальний курган,

Край беріз твоїх тихих

замисленим явором стати.

...Хоча б оддалік. [3, с 40]

Барыс Алейнік лаканічна і дакладна ахарактарызаваў геакультурную прастору Беларусі праз традыцыйна фальклорны вобраз, прасторавы маркёр ціхіх бяроз. Падобная формула выяўлення айчыннай прасторы з'яўляецца сваеасаблівым беларускім нацыянальнага брэндам, замацаваным ў выглядзе песні «Вы шуміце, шуміце» на словы Н. Гілевіча, музыку Э. Ханка ў выкананні музычнага калектыву «Сябры». Гэты прыклад сведчыць на карысць таго, як прасторавыя вобразы, яскрава i трапна дэманструючы нацыянальны стыль жыцця, пераўтвараюцца ў каштоўнасны фактар прэзентацыі і пазнавання краіны ў міжнацыянальных зносінах. У рэпертуар «Сяброў» увайшла і песня «Памяць Беларусіі» (1984) на словы Б. Алейніка, музыку М. Сацуры. 
Ва ўвязцы з прасторавымі вобразамі, на іх фоне ў вершаваных творах Б. Алейніка заўсёды разгортваецца ўнікальны летапіс пачуццяў, эмацыянальна насычаных перажыванняў лірычных герояў. Таму прасторавыя вобразы знешняга свету практычна заўсёды арганічна i паслядоўна афармляюцца ў пейзаж чалавечай душы.

За рікою тильки вишні...

Тільки вишні... тільки вишні

Та дорога за тумани утіка.

I ніхто мене не чує,

I ніхто мені не пише,

I ніхто мене не жде і не гука [3, с. 132].

Вішні за рэчкай як тыповы атрыбут класічнага ўкраінскага пейзажа (прыгадаем «Садок вішнёвы каля хаты» Тараса Шаўчэнкі) маляўніча дэкаруюць насычаную рамантычна-пачуццёвую сферу верша, узмацняюць лірычны настрой, схіляюць да спавядальнасці і светлага суму. Менавіта ў лірыцы кахання паэт знаходзіць найбольш блізкія асацыяцыі, арганічнае перапляценне пачуццяў і прыродна-прасторавай вобразнасці пры стварэнні інтымнай атмасферы пяшчотных стасункаў. Касмічная вобразнасць дазваляе паэту падкрэсліць рамантычную ўзнёсласць пачуцця, узвышанасць, а магчыма і недасягальнасць аб’екта пакланення:

Ти - зорею. А я - кленом...

$$
\text { Ти - зорею... }
$$

Ах, коли б так і лишилось у віках!

I ходив би поміж небом і землею

Білий вітер у пухнастих чобітках [3, с 90].

У кантэксце спасціжэння-адкрыцця навакольнага свету і чалавека ў ім арганічна рэалізуецца аўтарская задума шматграннага выяўлення лірычнай асобы ў адзінстве яе маральна-духоўных, псіхалагічна-ментальных і сацыяльных характарыстык. 
Праз зварот да самых простых, непасрэдна чалавечых абставін, паўсядзённа-побытавых і натуральна-прыродных ўмоў існавання ў паэзіі Б. Алейніка паўнакроўна і шматпланава выяўляецца маральны патэнцыял чалавека, спасцігаецца адмысловая логіка душы, першародныя прыроднакультурныя арыенціры.

Я в центрі кола, визначенім сонцем,

Поглиблю руку в чорний чорнозем -

І стеля над готичним храмом сосен

Спаде на мене зливою озер.

Тоди гукну:

- Беріть планети з бою,

Ламайте світ дюралевим крилом,

А я лишуся на землі вербою,

3 якої перше колесо пішло [5, с 68].

Аўтарская ідэнтыфікацыя з дрэвам, вярбою, з якой пайшло першае кола дэманструе не толькі першапачатак жыцця, але і ўкаранёнасць у глебу, прывязанасць чалавека да сваёй зямлі, адвечныя трывалыя сувязі з украінскім нацыянальным грунтам. Гэты грунт ахарактарызаваны ў вершы лаканічна, але цэласна і змястоўна праз вобразны рад: сонца, чарназём, сосны, азёры. На прыкладзе твора відавочна, як канкрэтыка, выяўленчая пластыка візуальнапрасторавых малюнкаў у паэзіі Б. Алейніка карэлюе з маштабным поступам эпохі, выхадам да глабальных, касмічных тэм, рамантычна ўзнёслых парыванняў.

Паэзія Б. Алейніка перадае напружаны рух па асваенню навакольнага свету i спасціжэння-пошуку ў ім сябе. Аўтарская самаідэнтыфікацыя адбываецца ў прасторава разгорнутых каардынатах, населеных прасторава выпуклымі вобразамі: месяц, мандаліна, кропля, кропка. 
Світ глибокий, мов колодязь.

Де я в ньому? Крикнув: «Де я?!»

Лунко злинуло відлуння

До галактик від воріт.

Вдалину подаленіло,

Лагідно торкнуло місяць,

Місяць, ніби мандоліна, -

Ліна-діна - забринів.

В цьому дивному огромі

Де я? Хто я? Крапелина.

Крапе... (лине): лина... ина...

Крапка у кінці рядків [3, с 85].

Гэта прасторавая выпукласць забяспечвае энергетычную пульсацыю аб’ектаў, якая надае ім іерархічна новыя прасторавыя ўласцівасці. У такім кантэксце кропка, з якой атаясамлівае сябе аўтар, патэнцыіруецца мысленчым зарадам і ўспрымаецца не як заканчэнне, а як пачатак, заканамерны пераход у новую якасць і ступень. Падобны эстэтычны прыём стварэння аб'ёмнага 3D малюнка скарыстоўваецца і ва ўзгаданым вершы «Я ў цэнтры кола, вызначаным сонцам», i y̆ шматлікіх іншых творах мастака. 3 дапамогай прасторавых вобразаў у паэзіі Б. Алейніка «зазямляюцца», робяцца больш зразумелымі, бачнымі самыя глыбокія роздумы, развагі, пластычна, наглядна і жывапісна раскрываюцца думка, пачуццё, настрой, транслюецца жыццёвае крэда мастака:

Мати сіяла сон

під моїм під вікном,

А вродив соняшник.

I тепер: хоч буран, хоч бур'ян чи туман,

А мені- сонячно.

Мати сіяла льон

під моїм під вікном,

А зійшло полотно.

I тепер: хоч яри, хоч вітри крізь бори,

А я йду все одно. 
Тільки квітом своїм

При моєму вікні

Не опав соняшник.

Я несу його в світ,

Щоб не тільки мені,

$$
\text { Щоб і вам - сонячно [3, с 93]. }
$$

Такім чынам, ужыванне прасторавых вобразаў у паэтычным дыскурсе Б. Алейніка ніколі не бывае выпадковым, абмежаваным дэкаратыўнымі функцыямі. Апасродкам прасторавай канкрэтызацыі і аб'ёмнасці вобразаў мастацкага малюнка ўвасобленыя ў ім высокія ісціны, маральныя катэгорыі, філасофскія рэфлексіі набываюць паўнакроўнае натуральна-прыроднае абгрунтаванне або, па трапнай заўвазе М. Ільніцкага, «жывую плоць». Трывала ўкаранёнае ў народна-нацыянальную жыццёвую стыхію, паэтычнае слова таленавітага майстра пераканальна прэзентуе маральна-духоўныя скарбы ўкраінскай нацыі, яе духоўны суверэнітэт, самадастатковасць і ў той жа час адкрытасць і настроенасць на дыялог. У мастацкім слове пісьменніку бачыўся дзейсны сродак фарміравання эстэтычных густаў і каштоўнасных арыенціраў, здзяйснення чалавечых і грамадскіх кантактаў, міжнацыянальнага духоўнага збліжэння i ўзаемаразумення. Сваім паэтычным дарам, нястомнай перакладчыцкай працай, паслядоўнай грамадскай пазіцыяй Барыс Алейнік зрабіў значны ўнёсак у працэсы духоўнага ўзаемадзеяння 3 перадавымі агульнаславянскімі тэндэнцыямі культурна-гістарычнага, інтэлектуальнага развіцця. Плённым і перспектыўным бачыцца вывучэнне асаблівасцей прасторавай паэтыкі Барыса Алейніка ў параўнальным аспекце 3 творамі беларускіх аўтараў.

\section{ЛІТЕРАТУРА}

1. Лотман Ю. М. Структура художественного текста / Ю. М. Лотман. М. : Искусство, 1970. 384 с.

2. Ільницький М. М. На спокій права не дано. Поезія Бориса Олійника / М.М. Ільницький. К. : Молодь, 1980. 112 с. 
3. Олійник Б. Вибрані твори. Т. 1: Вірші. Поеми [укладачі, коментарі, примітки: А. Я. Слободяник, М.В.Луків, Д.В.Янко] / Б. Олійник. К. : Українська енциклопедія, 2005. $604 \mathrm{c}$.

4. Бородай Т. Ю. Семантика слова chora у Платона / Т. Ю. Бородай. Bonpocbl классической филологии. М. : Изд-во Моск. ун-та, 1984. Вып. 8. С. 58-73.

5. Олійник Б. І. Основи: Поезії. Поеми. / Б. Олійник. К. : Дніпро, 2015. 696 с.

\section{REFERENCES}

1. Lotman, Yu. N. Struktura khudozhestvennogo teksta [Structure of artistic text]. Moskva, Iskusstvo, 1970. 384 p [In Russian].

2. Ilnyts'kyi, M. M. Na spokij prava ne dano. Poeziya Borysa Olijnyka [No rules for tranquility. Poetry of Borys Oliynyk]. Kyiv: Molod', 1980. 112 p [In Ukrainian].

3. Olijnyk, B. Vybrani tvory [Selected works]. Vol. 1: Virshi. Poemy [Poetry]. Kyiv: Ukrayins'ka entsyklopediya, 2005. 604 p [In Ukrainian].

4. Boroday, T. Yu. Semantika slova chora u Platona [Plato's semantics of word chora]. Voprosy klassicheskoy filologiyi [Questions of classical philology]. Moskva: Izdatel'stvo Moskovskogo universiteta, 1984. Vol. 8. Pp. 58-73 [In Russian].

5. Olijnyk, B. Osnovy: Poeziyi. Poemy [The Basics: Poetry]. Kyiv: Dnipro, 2015. 696 p. [In Ukrainian].

\section{АННОТАЦИЯ}

\section{Шаладонова Ж. С. Пространственные образы в поэтическом дискурсе Бориса Олейника}

В статье раскрываются идейно-эстетические особенности пространственных образов в поэзии Бориса Олейника, осмысливается их символическая содержательность в авторской самоидентификации, выражении жизненного и творческого кредо, трансляции раздумий, чувств, настроений. Автор статьи приходит к выводам, что употребление пространственных образов в поэтическом дискурсе Б. Олейника никогда не бывают случайным, ограниченным декоративными функциями. Выразительная пространственная конкретизация и объёмность образов художественного рисунка даёт возможность наглядно и естественно обосновать отображённые в нём нравственные категории, философские рефлексии, эмоционально-чувственную сферу.

Ключевые слова: пространственные образы, символ, национальный, самоидентификация.

\section{ABSTRACT \\ Shaladonova $\mathrm{Zh}$. Spatial images in the poetic discourse of Borys Oliynyk}

The ideological and aesthetic features of spatial images in the poetry of Borys Oliynyk are revealed in the article, its symbolic meaningfulness is interpreted in author's self-identification, expression of life and creative credo, translation of thoughts, feelings, moods.

It is noted that such features as extreme frankness of lyrical confession, subtle analysis of the human spiritual world and at the same time philosophically thoughtful view of the essence of events, satirical and civic pointy talent, patriotic orientation are inherent in B. Oliynyk's creativity. Thanks to these characteristics, the artistic picture of the world of the poet becomes philosophical and analytical, due to which spatial images become rather abstract, even conditional. That is why Borys Oliynyk's poetry doesn't characterize detailed landscape sketches with their inherent attributes of the Ukrainian natural landscape and way of life. In the works of the author there is a transformation of the natural factor into the creative element, thanks to which the axiological, spiritual and philosophical content and the emotional and psychological richness of being are transmitted. The artist's vision converts ordinary features into masterfully written memorable character images.

Key words: spatial images, symbol, national, self-identification. 